\title{
Statistical Machine Translation Pada Bahasa Lampung Dialek Api Ke Bahasa Indonesia
}

\author{
Permata $^{1}$, Zaenal Abidin ${ }^{2}$ \\ ${ }^{1}$ Fakultas Teknik dan Ilmu Komputer, Prodi Informatika, Universitas Teknokrat Indonesia, Bandar Lampung, Indonesia \\ ${ }^{2}$ Fakultas Teknik dan Ilmu Komputer, Prodi Sistem Informasi, Universitas Teknokrat Indonesia, Bandar Lampung, Indonesia \\ Email: ${ }^{1}$ permata@teknokrat.ac.id, ${ }^{2}$ zabin@teknokrat.ac.id \\ Email Penulis Korespondensi: ${ }^{2}$ zabin@teknokrat.ac.id
}

\begin{abstract}
Abstrak-Pada penelitian ini, penerjemahan secara otomatis pada bahasa Lampung dialek api ke bahasa Indonesia dilakukan dengan pendekatan statistical machine translation (SMT). Penerjemahan bahasa Lampung ke bahasa Indonesia dapat dilakukan menggunakan kamus. Alternatif lainnya adalah menggunakan pemanfaatan korpus paralel bahasa Lampung dan terjemahannya dalam bahasa Indonesia dengan pendekatan SMT. Pada pendekatan SMT dilakukan dengan beberapa fase. Dimulai dari fase prapemrosesan yang merupakan tahapan awal untuk mempersiapkan korpus parallel. Kemudian dilanjutkan dengan fase training, yakni fase pengolahan korpus parallel untuk memperoleh language model dan translation model. Selanjutnya fase testing, dan diakhiri dengan fase evaluasi. Pengujian SMT menggunakan 25 kalimat tunggal tanpa out-ofvocabulary (OOV), 25 kalimat tunggal dengan OOV, 25 kalimat majemuk tanpa OOV dan 25 kalimat majemuk dengan OOV. Hasil pengujian penerjemahan kalimat bahasa Lampung ke bahasa Indonesia menunjukan nilai akurasi Bilingual Evaluation Undestudy (BLEU) yang diperoleh adalah $77.07 \%$ pada 25 kalimat tunggal tanpa out-of-vocabulary (OOV), $72.29 \%$ pada 25 kalimat tunggal dengan OOV, $79.84 \%$ pada 25 kalimat majemuk tanpa OOV dan $80.84 \%$ pada 25 kalimat majemuk dengan OOV.
\end{abstract}

Kata Kunci: Korpus Paralel, Mono Korpus, Statistical Machine Translation, Bahasa Lampung, BLEU

Abstract-In this research, automatic translation of the Lampung dialect into Indonesian was carried out using the statistical machine translation (SMT) approach. Translation of the Lampung language to Indonesian can be done by using a dictionary. Another alternative is to use the Lampung parallel body corpus and its translation in Indonesian with the SMT approach. The SMT approach is carried out in several phases. Starting from the pre-processing phase which is the initial stage to prepare a parallel corpus. Then proceed with the training phase, namely the parallel corpus processing phase to obtain a language model and translation model. Then the testing phase, and ends with the evaluation phase. SMT testing uses 25 single sentences without out-of-vocabulary (OOV), 25 single sentences with OOV, 25 compound sentences without OOV and 25 compound sentences with OOV. The results of testing the translation of Lampung sentences into Indonesian shows the accuracy of the Bilingual Evaluation Undestudy (BLEU) obtained is $77.07 \%$ in 25 single sentences without out-of-vocabulary (OOV), $72.29 \%$ in 25 single sentences with OOV, $79.84 \%$ at 25 compound sentences without OOV and $80.84 \%$ at 25 compound sentences with OOV.

Keywords: Paralel Corpus, Mono Corpus, Statistical Machine Translation, Lampung Language, BLEU

\section{PENDAHULUAN}

Kondisi saat ini di Indonesia, dari 617 bahasa daerah yang teridentifikasi terdapat 15 bahasa daerah yang dinyatakan punah dan 139 lainnya dalam status terancam punah. Informasi ancaman kepunahan bahasa daerah dinyatakan oleh Dadang Sunendar selaku Kepala Badan Pembinaan dan Pengembangan Bahasa Kementerian Pendidikan dan Kebudayaan melalui hasil risetnya, usai menghadiri Kongres Bahasa Daerah Nusantara di gedung Merdeka Bandung pada tahun 2016 [1]. Dalam konteks menghindari ancaman kepunahan tersebut, pelestarian bahasa daerah menjadi teramat penting karena bahasa merupakan salah satu identitas penting suatu daerah. Bahasa daerah merupakan bentuk ekspresi kultural utama suatu etnis atau daerah, tidak terkecuali untuk bahasa Lampung. Bahasa Lampung merupakan identitas penting dari kebudayaan Lampung. Jika tidak ada upaya menjaga bahasa Lampung maka akan mengakibatkan sirnanya kebudayaan masyarakat Lampung [2].

Upaya menjaga dan melestarikan bahasa daerah tidak hanya harus dilakukan oleh pemerintah pusat, melainkan membutuhkan juga peran aktif pemerintah daerah, masyarakat, serta institusi pendidikan atau lembaga pendidikan. Setiap provinsi memiliki bahasa daerah, baik yang berbentuk tulisan maupun ucapan, termasuk salah satunya provinsi Lampung yang memiliki bahasa daerah dengan dua dialek utama, yaitu dialek Api dan dialek Nyo. Upaya pemerintah provinsi Lampung untuk melestarikan bahasa Lampung, salah satunya diberikan melalui pendidikan bahasa Lampung sebagai muatan lokal wajib dari mulai sekolah tingkat dasar sampai sekolah tingkat menengah atas. Hal ini sesuai peraturan gubernur nomor 39 tahun 2014 tentang mata pelajaran bahasa dan aksara Lampung sebagai muatan lokal wajib pada jenjang satuan pendidikan dasar sampai menengah atas dan didukung oleh ketersediaan buku ajar mulai dari SD, SMP dan SMA, berikut kamus bahasa Lampung.

Pemanfaatan kakas berbasis komputer dapat digunakan sebagai upaya untuk melestarikan bahasa Lampung secara digital sesuai perkembangan teknologi saat ini, diantaranya dengan membangun kamus digital dan mesin penerjemah. Salah satu contoh kamus digital bahasa daerah dapat diakses melalui laman www.kamusdaerah.com. Kamus digital memiliki kemampuan dalam menerjemahkan bahasa daerah ke bahasa Indonesia dengan pendekatan yang digunakan adalah menerjemahkan kata per kata, walaupun tidak efektif ketika dikerjakan secara manual. Solusi alternatifnya adalah dengan membuat aplikasi mesin penerjrmah. Mesin penerjemah bisa berbasis kamus 
dan mesin penerjemah berbasis data korpus paralel bahasa. Untuk mesin penerjemah, salah satu kakas mesin penerjemah yang ada saat ini adalah mesin penerjemah google yang dapat diakses melalui laman https://translate.google.com. Mesin ini dapat diakses dengan mudah, akan tetapi pada mesin penerjemah google hanya terdapat dua bahasa daerah yang tersedia yaitu bahasa Jawa dan bahasa Sunda. Bahasa Lampung sendiri belum tersedia di mesin penerjemah google.

Pendekatan pembangunan mesin penerjemah dapat dilakukan dengan tiga pendekatan, yaitu (1) pendekatan secara langsung atau Direct Machine Translation (DMT), (2) pendekatan berbasis aturan atau Rule-based Machine Translation (RBMT) dan (3) pendekatam berbasis korpus paralel atau disebut juga data-driven [3]. Pada DMT, komponen utama yang dibutuhkan adalah kamus dwi bahasa. Pembangunan mesin penerjemah dengan pendekatan berbasis aturan atau RBMT maka akan membutuhkan aturan untuk menganalisis kalimat bahasa sumber, aturan untuk mentransformasikan representasi hasil analisis bahasa sumber, serta aturan untuk membangkitkan kalimat pada bahasa tujuan, sedangakan pembangunan mesin penerjemah dengan pendekatan berbasis data-driven yang membutuhkan korpus paralel [3]. SMT termasuk dalam pendekatan mesin penerjemah berbasis data-driven yang membutuhkan korpus paralel [3].

Penerjemahan secara otomatis pada bahasa daerah dengan pendekatan DMT telah dilakukan oleh para peneliti. Beberapa penelitian tersebut diantaranya penelitian penerjemahan bahasa Indonesia ke aneka bahasa Sulawesi [4], penelitian penerjemahan bahasa Indonesia ke bahasa Jawa [5], [6], penelitian penerjemahan bahasa Indonesia ke bahasa Jawa menggunakan interpolation search [7], penelitian penerjemahan bahasa Bali ke bahasa Indonesia [8], penelitian penerjemahan bahasa Pali ke bahasa Sinhala menggunakan kamus dimana kedua bahasa tersebut ada di Sri Lanka [9], penelitian penerjemahan bahasa Kannada ke bahasa Telugu menggunakan kamus dimana kedua bahasa tersebut ada di India [10], penelitian penerjemahan secara otomatis bahasa daerah dengan menggunakan SMT telah dilakukan diantaranya oleh [5], [11]. Suryani, dkk melakukan penelitian penerjemahan secara statistik pada pasangan bahasa Sunda-Indonesia dengan menerapkan PoS Tag pada model translasinya. Nugroho, dkk melakukan penelitian penerjemahan secara statistik pada frasa untuk pasangan bahasa Indonesia Jawa. Sebelum November 2016, SMT ini digunakan sebagai pendekatan dalam mesin penerjemah google, kemudian mesin penerjemah google beralih ke teknologi neural machine translation (NMT). Penelitian SMT bahasa Bugis Wajo ke bahasa Indonesia [12], penelitian bahasa Jepang ke bahasa Indonesia dengan berbagai model termasuk dengan model SMT [13], penelitian SMT bahasa Indonesia ke bahasa Dayak dari aspek model bahasanya [14], penerjemahan dokumen bahasa Inggris ke bahasa Indonesia dengan pendekatan SMT [15].

Bahasa Lampung sendiri sebagai suatu bahasa daerah yang wajib dilestarikan maka diperlukan upaya untuk mewujudkannya. Penelitian penerjemahan kalimat bahasa Lampung dialek api telah menjadi objek penelitian penerjemahan secara otomatis dengan menggunakan pendekatan Neural Machine Translation (NMT) tanpa attention [16] dan Neural Machine Translation (NMT) dengan attention [17]. Adapun penilaian akurasi yang digunakan pada penelitian SMT dan NMT adalah menggunakan nilai Bilingual Evaluation Under-study (BLEU) [18].

Penelitian ini bertujuan untuk melakukan ujicoba penerjemahan bahasa Lampung dialek api menggunakan Moses Decoder untuk penerjemahan bahasa Lampung - Indonesia secara statistik. Adapun batasan masalah yang diterapkan dalam penelitian ini adalah (1) korpus paralel berasal dari buku teks dialek api yang digunakan di sekolah di provinsi Lampung dan kalimat melalui penutur asli bahasa tersebut, (2) testing data menggunakan masukan bahasa Lampung dialek api, (3) tidak menggunakan bahasa sastra Lampung khususnya novel bahasa Lampung.

\section{METODOLOGI PENELITIAN}

Penelitian SMT pada bahasa lampung dialek api ke bahasa Indonesia menggunakan tahapan eksperimen yang digambarkan pada gambar 1 di bawah ini.

\subsection{Analisis Masalah Penerjemahan Bahasa Lampung}

Untuk dapat melakukan penerjemahan bahasa Lampung - bahasa Indonesia dengan baik maka perlu digali masalah yang ditemui saat menerjemahkan bahasa Lampung - Indonesia secara manual. Sebuah upaya dilakukan dengan mewawancarai guru bahasa Lampung. Bahasa Lampung adalah bahasa asli masyarakat Lampung. Di propinsi Lampung secara umum terbagi menjadi dua dialek utama yaitu dialek Api dan dialek Nyo.

Pada penelitian ini hanya dilakukan pengamatan secara seksama terhadap bahasa Lampung dialek Api. Hasil wawancara dengan guru bahasa Lampung menunjukan bahasa Lampung memiliki kemiripan stuktur tata bahasa dengan bahasa Indonesia. Dalam bahasa Lampung dikenal struktur kalimat yang terdiri dari subjek, predikat, objek, keterangan seperti dalam bahasa Indonesia. 


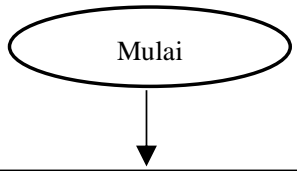

Wawancara dengan ahli bahasa Lampung

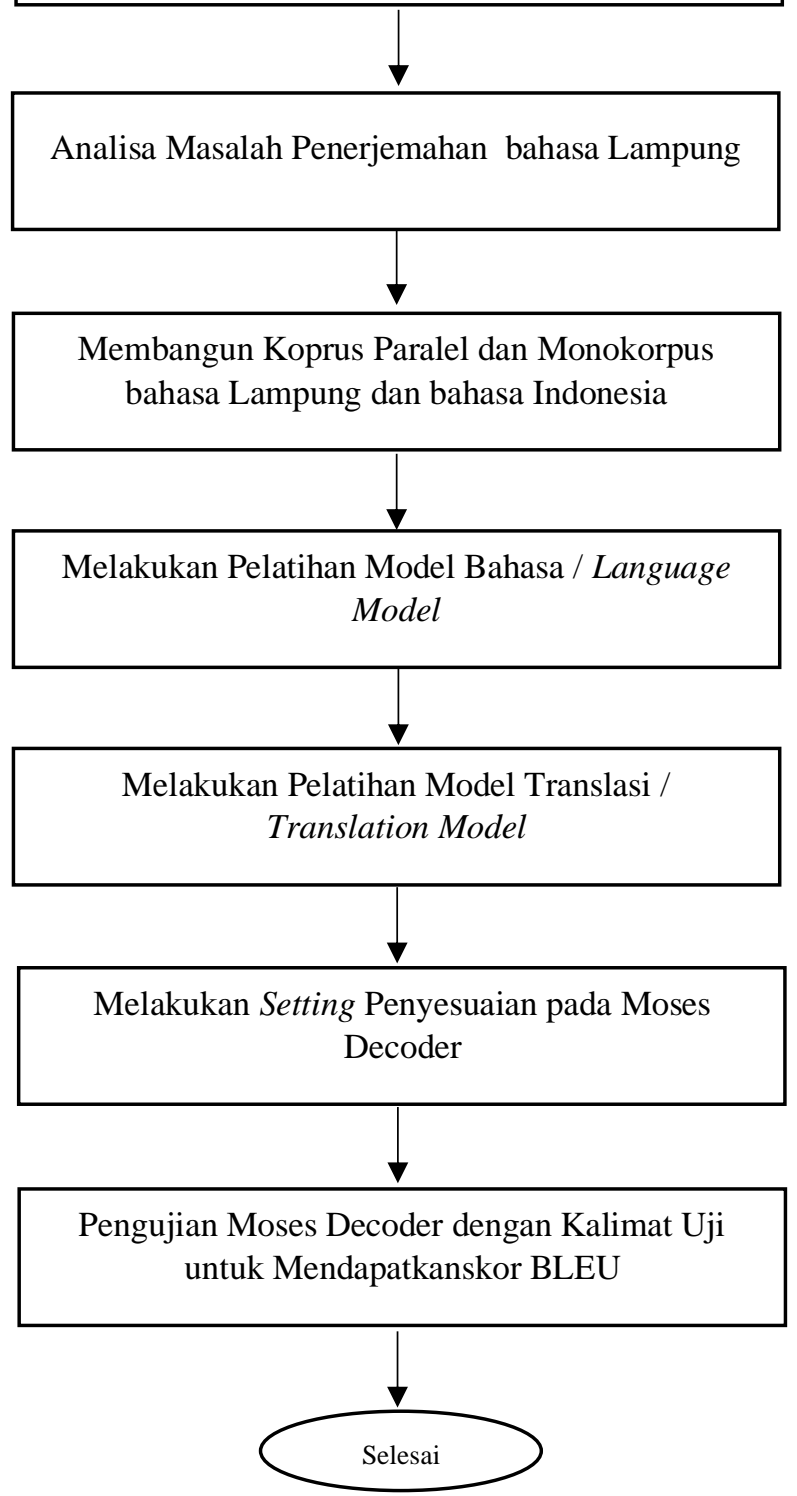

Gambar 1. Tahapan eksperimen membangun SMT bahasa Lampung - Indonesia

Dalam bahasa Lampung juga terdapat berbagai jenis kalimat, seperti kalimat tunggal, kalimat majemuk, kalimat tanya, kalimat perintah dan lain-lain [19]. Kosa katadalam bahasa Lampung, khususnya dialek api, jumlahnya lebih sedikit dibanding dengan bahasa Indonesia. Sebuah kamus bahasa Lampung - Indonesia yang diterbitkan oleh penerbit gunung pesagi Bandar Lampung berisi 4071 kata dialek Api, sedangkan kamus bahasa Indonesia edisi ke-5 yang diterbitkan oleh penerbit gramedia pustaka utama memiliki 118000 kata. Beberapa contoh kalimat dalam bahasa Lampung dan terjemahannya dapat dilihat pada tabel 1 di bawah ini.

Tabel 1. Bahasa Lampung dan terjemahannya dalam bahasa Indonesia

\begin{tabular}{ll}
\hline \multicolumn{1}{c}{ Bahasa Lampung } & \multicolumn{1}{c}{ Bahasa Indonesia } \\
\hline Ani tulung akukko wai sina & Ani tolong ambilkan air itu \\
Makku lagi mepoh kawai di wai & Ibuku sedang mencuci baju di sungai \\
Gham lapah mit pasagh & Kita pergi ke pasar \\
Lapah gham sholat di masjid & Mari kita sholat di masjid \\
\hline
\end{tabular}




\begin{tabular}{ll}
\hline Ketua kelas sai ngator barisan di kelasni & Ketua kelas yang mengatur barisan di kelasnya \\
Ya tetap di kelas sai ulah mak cakak kelas & $\begin{array}{l}\text { Dia tetap di kelas satu karena tidak naik kelas } \\
\text { tiga kali }\end{array}$ \\
telu kali & \\
\hline
\end{tabular}

Pada tabel 1 di atas terdapat beberapa kata yang memiliki makna berbeda tergantung konteks kalimat atau posisi pada kalimat, seperti kata wai, lapah, sai. Penggunaan kamus bahasa Lampung harus menerjemahkan satu per satu dan memilih makna kata yang tepat secara manual agar kalimat tersebut dapat dipahami dengan baik. Penerjemahan kalimat bahasa Lampung sangat penting memperhatikan konteks kalimat yang digunakan agar dapat menghasilkan terjemahan yang sesuai. Pada bahasa Lampung juga terdapat beberapa kata yang memiliki satu makna yaitu lapah, mit, tandak, lijing yang semuanya bermakna pergi. Beberapa partikel seperti kudo, do, pai, tah semuanya memiliki satu makna yaitu lah, sebuah partikel dalam bahasa Indonesia.

Proses penerjemahan bahasa Lampung ke bahasa Indonesia dapat dilakukan secara komputasi dengan dua pendekatan, yaitu pertama dengan pendekatan penerjemahan kalimat bahasa Lampung secara langsung kata per kata dengan menggunakan kamus Lampung-Indonesia atau disebut direct machine translation dan kedua penerjemahan kalimat bahasa Lampung dengan pendekatan berbasis data-driven atau korpus paralel., Pada pendekatan berbasis data-driven atau korpus paralel, metode yang akan digunakan adalah statistical machine translation (SMT).

Pendekatan berbasis data-driven atau korpus paralel membutuhkan keberadaan data teks daring yang memadai. Faktanya tidak ditemukan korpus paralel bahasa Lampung-Indonesia. Ketiadaan korpus paralel bahasa Lampung - Indonesia sehingga mengharuskan untuk membuat korpus paralel secara manual berdasarkan buku bahasa Lampung sebagai referensi sekolah, buku percakapan sehari-hari bahasa Lampung dan buku afiksasi verba bahasa Lampung.

\subsection{Solusi Ketiadaan Korpus Paralel}

Ketiadaan korpus parallel bahasa Lampung-Indonesia diatasi dengan cara melakukan wawancara secara langsung ke penutur asli bahasa Lampung dialek api dan mengumpulkan kalimat yang terdapat pada buku acuan bahasa Lampung dialek api yang digunakan di provinsi Lampung. Setelah wawancara dan pengumpulan kalimat dari buku berhasil dilakukan maka langkah selanjutnya adalah mengetikkan ulang bahasa Lampung dan terjemahannya dalam bahasa Indonesia dengan menggunakan aplikasi gedit yang ada di Linux Ubuntu 16.04, kemudian dilakukan penggalian informasi statistik data dari korpus parallel tersebut.

\subsection{Pengumpulan Data}

Penelitian penerjemahan bahasa Lampung - Indonesia secara komputasi membutuhkan bahan berbentuk kalimatkalimat bahasa Lampung yang telah memiliki padanan artinya dalam bahasa Indonesia. Kalimat-kalimat yang ada dalam penelitian ini berasal hasil wawancara dan dari buku acuan belajar bahasa Lampung, LKS belajar bahasa Lampung dan percakapan sehari-hari bahasa Lampung. Kalimat-kalimat tersebut telah diketik secara manual untuk membuat korpus paralel dan jumlahnya mencapai 3000 kalimat. Pada saat pembuatan korpus paralel yang dilakukan secara manual juga dilakukan prapemrosesan kalimat secara secara manual baik pada bahasa Lampung maupun bahasa Indonesia yaitu dengan cara : (1) kalimat dibuat menggunakan semua huruf kecil, (2) antar kalimat dipisahkan oleh spasi termasuk tanda koma, tanda tanya, tanda seru dan titik.

Kalimat-kalimat, bahasa Lampung dialek api dan terjemahannya dalam bahasa Indonesia, yang digunakan dalam penelitian ini dibuat secara mandiri dengan cara mengetikkan ulang karena faktor ketiadaan bahan yang dapat diambil secara daring dari laman. 3000 kalimat yang telah dibuat sebagai korpus paralel adalah berasal dari buku sekolah dasar (SD) dan lembar kerja siswa (LKS) tingkat SD yang digunakan di provinsi Lampung, buku percakapan sehari-hari bahasa Lampung serta buku afiksasi verba bahasa Lampung.

\subsection{Statistik Data Korpus Paralel}

Informasi statistik data yang terkandung pada 3000 kalimat korpus paralel disajikan dalam bentuk tabel guna memudahkan dalam penelusurannya. Diawali dari penyajian informasi atau statistik data pada bahasa sumber yaitu bahasa Lampung dan bahasa tujuan yaitu bahasa Indonesia. Tingkat kemunculan kata juga menjadi perhatian tersendiri guna digali hal tersebut akan membantu pada tahapan analisis selanjutnya. Out of vocobulary (OOV) adalah kata yang tidak ada dalam korpus paralel yang digunakan dalam penelitian ini.

Tabel 2. Statistik data korpus paralel bahasa Lampung - bahasa Indonesia

\begin{tabular}{lcc}
\hline \multicolumn{1}{c}{$\begin{array}{c}\text { Korpus Paralel Lampung - } \\
\text { Indonesia }\end{array}$} & $\begin{array}{c}\text { Bahasa } \\
\text { Lampung }\end{array}$ & $\begin{array}{c}\text { Bahasa } \\
\text { Indonesia }\end{array}$ \\
\hline Jumlah kalimat & 3000 & 3000 \\
Rata-rata jumlah kata per kalimat & 5,1 & 5,4 \\
Rata-rata jumlah karakter per kata & 6,1 & 6 \\
Jumlah kata & 3945 & 3141 \\
Jumlah simbol non kata & 23 & 23 \\
\hline
\end{tabular}


JURNAL MEDIA INFORMATIKA BUDIDARMA

Volume 4, Nomor 3, Juli 2020, Page 519-528

ISSN 2614-5278 (media cetak), ISSN 2548-8368 (media online)

Available Online at https://ejurnal.stmik-budidarma.ac.id/index.php/mib

DOI 10.30865/mib.v4i3.2116

Pengujian aplikasi dilakukan dengan menggunakan 100 kalimat terdiri dari 25 kalimat tunggal tanpa out of vocobulary (OOV), 25 kalimat tunggal dengan OOV, 25 kalimat majemuk tanpa OOV dan 25 kalimat majemuk dengan OOV.

\subsection{Statistical Machine Translation}

Dalam membangun mesin penerjemah statistik bahasa Lampung ke bahasa Indonesia, diawali dengan merancang arsitektur sistem. Arsitektur dari mesin penerjemah statistik dapat dilihat pada Gambar 2 di bawah ini.

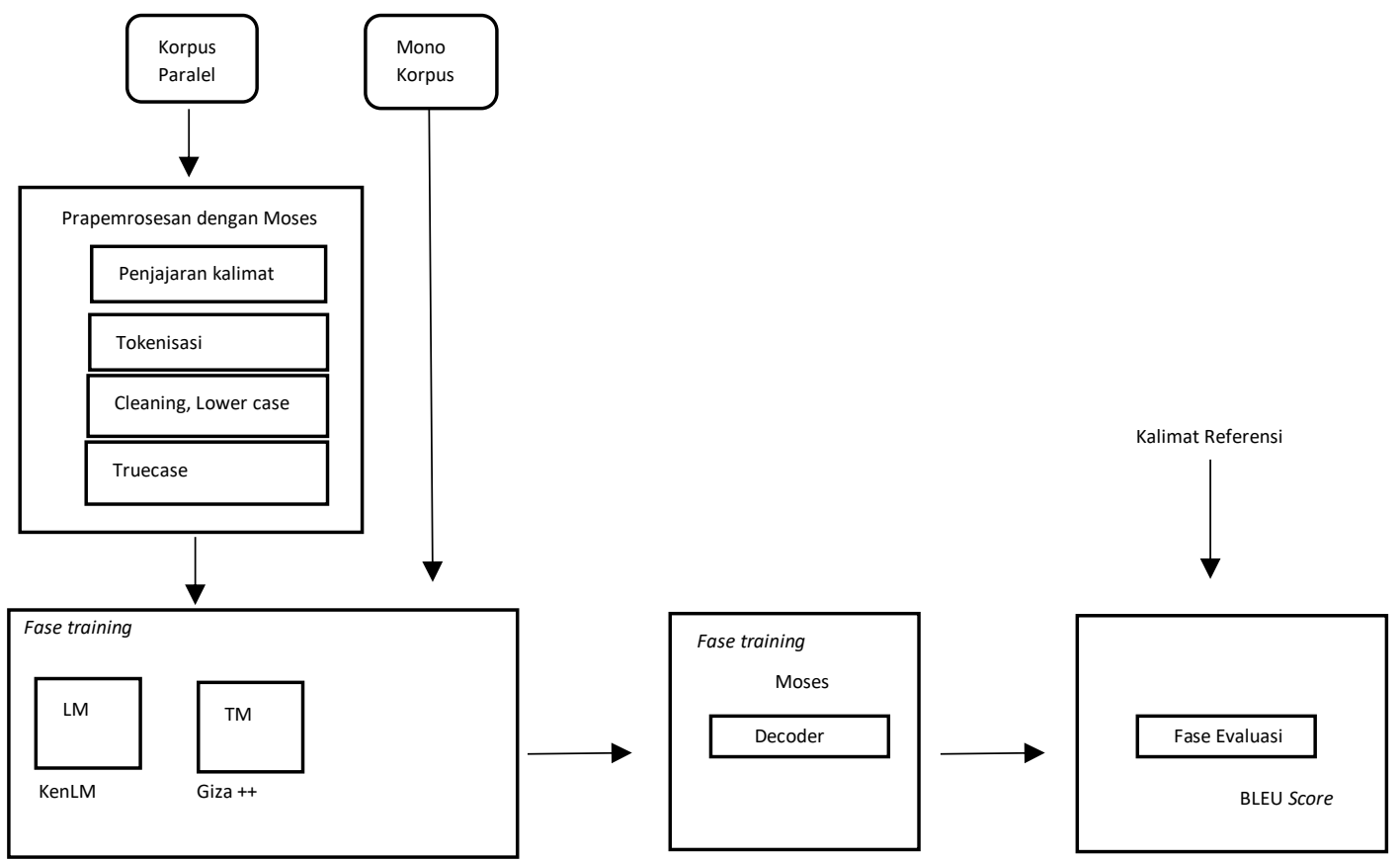

Gambar 2. Arsitektur dalam membangun SMT bahasa Lampung - Indonesia

Arsitektur pada Gambar 1 di atas terdiri dari beberapa fase. Dimulai dari fase prapemrosesan yang merupakan tahapan awal untuk mempersiapkan korpus parallel. Kemudian dilanjutkan dengan fase training, yakni fase pengolahan korpus parallel untuk memperoleh language model dan translation model. Selanjutnya fase testing, dan diakhiri dengan fase evaluasi. Untuk alat-alat (tools) yang digunakan dalam ujicoba SMT pada bahasa Lampung-Indonesia adalah :

1. Linux ubuntu 16.04 LTS, sistem operasi yang digunakan dalam menjalankan Moses.

2. Moses, perangkat lunak untuk proses preprosesing dan decoding.

3. KenLM, perangkat lunak telah terpasang di Moses, untuk Language Model.

4. Giza++, perangkat lunak untuk Translation Model.

5. BLEU, perangkat lunak untuk proses evaluasi.

Untuk bahan korpus paralel yang digunakan adalah buku ajar bahasa Lampung tingkat sekolah dasar dan untuk mono korpus bahasa Indonesia diambil dari laman www.manythings.org sebanyak 6702 kalimat dan ditambah korpus bahasa Indonesia sebanyak 3000 kalimat.

\section{HASIL DAN PEMBAHASAN}

\subsection{Implementasi SMT Pada Moses Decoder}

Fase prapemrosesan SMT pada Moses Decoder terdiri dari beberapa bagian, yakni penjajaran kalimat, tokenisasi, cleaning, lowercase filtering, dan truecase. Penjajaran kalimat adalah proses menjajarkan korpus paralel bahasa lampung dialek api dengan bahasa Indonesia sebagai terjemahannya. Tokenisasi diperlukan untuk memberi jarak antar kata termasuk juga memberi jarak antara kata dengan tanda baca yang ada, sedangkan lowercase merupakan proses untuk menyeragamkan besar-kecilnya huruf. Perintah yang digunakan dalam tokenisasi di Moses adalah sebagai berikut:

$\sim /$ mosesdecoder/scripts/tokenizer/tokenizer.perl -l lg < /corpus/training/training.lg-id.lg > /corpus/training.lg-id.tok.lg $\sim /$ mosesdecoder/scripts/tokenizer/tokenizer.perl -l id < /corpus/training/training.lg-id.id > $/$ corpus/training.lg-id.tok.id $\sim /$ mosesdecoder/scripts/tokenizer/tokenizer.perl -l id < /corpus/training/trainingmono.lg-id.id > /corpus/trainingmono.lgid.tok.id 
JURNAL MEDIA INFORMATIKA BUDIDARMA

Volume 4, Nomor 3, Juli 2020, Page 519-528

ISSN 2614-5278 (media cetak), ISSN 2548-8368 (media online)

Available Online at https://ejurnal.stmik-budidarma.ac.id/index.php/mib

DOI 10.30865/mib.v4i3.2116

\%/mosesdecoder/scripts/tokenizer/lowercase.perl -l id < /corpus/trainingmono.lg-id.tok.id >/corpus/trainingmono.lgid.tokLowercase.id

Pada proses truecasing ini setiap awal dari tiap kalimat dikonversi ke tempat yang paling mungkin. Perintah yang digunakan dalam truecasing di Moses adalah sebagai berikut:

\%/mosesdecoder/scripts/recaser/train-truecaser.perl --model /corpus/truecase-model.lg --corpus /corpus/training.lgid.tok.lg

/mosesdecoder/scripts/recaser/train-truecaser.perl --model /corpus/truecase-model.id --corpus /corpus/training.lgid.tok.id

/mosesdecoder/scripts/recaser/train-truecaser.perl --model /corpus/truecase-modelLowercase.id -corpus ।

$\sim /$ corpus/trainingmono.lg-id.tokLowercase.id

$\sim /$ mosesdecoder/scripts/recaser/truecase.perl --model /corpus/truecase-model.|g < /corpus/training.|g-id.tok.|g |

$>\sim$ corpus/training.Ig-id.true.lg

$\sim /$ mosesdecoder/scripts/recaser/truecase.perl --model /corpus/truecase-model.id < /corpus/training.lg-id.tok.id $\backslash$

$>\sim /$ corpus/training.Ig-id.true.id

$\sim /$ mosesdecoder/scripts/recaser/truecase.perl --model /corpus/truecase-model.id < /corpus/trainingmono.lg-

id.tokLowercase.id > /corpus/trainingmono.lg-id.trueLowercase.id

Cleaning adalah proses pemberian batasan panjang kalimat. Cleaning juga berfungsi untuk menghilangkan kalimat-kalimat yang tidak sejajajar. Perintah yang digunakan dalam cleaning di Moses adalah sebagai berikut:

/mosesdecoder/scripts/training/clean-corpus-n.perl /corpus/training.lg-id.true lg id /corpus/training.|g-id.clean 125

Fase berikutnya adalah fase training. Pada fase inilah language model dan translation model dilakukan. Languange model menggunakan perangkat lunak, dalam penelitian ini digunakan KenLM, yang telah disatukan kedalam Moses. Perintah yang digunakan dalam language model di Moses adalah sebagai berikut:

/mosesdecoder/bin/Implz -o $3<\sim$ corpus/trainingmono.lg-id.trueLowercase.id > trainingmono.lg-id.arpa.id \% mosesdecoder/bin/build_binary \trainingmono.lg-id.arpa.id \trainingmono.lg-id.blm.id

Untuk translation model digunakan perangkat lunak Giza++ yang didalamnya menerapkan algoritma Expectation Maximitation atau algoritma IBM model. Perintah yang digunakan dalam training di Moses adalah sebagai berikut:

nohup nice $\sim$ /mosesdecoder/scripts/training/train-model.perl -root-dir Hasiltraining1 -corpus /corpus/training.lg-id.clean -- $f$ Ig --e id -alignment grow-diag-final-and -reordering msd-bidirectional-fe -Im 0:3:\$HOME/Im/trainingmono.lg-id.blm.id:8 external-bin-dir /mosesdecoder/tools $>\&$ training.out \&

Khusus untuk translation model, pendekatan yang digunakan adalah berbasis frasa. yang di dalamnya terdapat beberapa tahapan. Tahapan tersebut dimulai dari penjajaran kata sampai dengan pembuatan berkas konfigurasi (configuration file) yang akan digunakan pada proses decoding. Fase testing adalah fase dalam menerjemahkan bahasa sumber ke bahasa target. Masukan berupa kalimat dalam bahasa sumber akan diterjemahkan ke dalam bahasa target. Fase ini juga merupakan fase decoding hasil dari fase training. Perintah yang digunakan dalam tuning di Moses adalah sebagai berikut:

nohup nice /mosesdecoder/scripts/training/mert-moses.pl /corpus/valid.lg-id.true.lg /corpus/valid.lg-id.true.id $\sim /$ mosesdecoder/bin/moses Hasiltraining1/model/moses.ini --mertdir /mosesdecoder/bin/ $\backslash \&>$ mert.out \&

Fase yang terakhir adalah fase pengevaluasian secara automatis dari hasil terjemahan yang diperoleh fase testing. Perintah yang digunakan dalam testing di Moses adalah sebagai berikut:

$\sim /$ mosesdecoder/bin/moses -f /working1/mert-work/moses.ini

\subsection{Hasil Pengujian Kalimat Bahasa Lampung dengan SMT}

Dengan menggunakan 3000 kalimat untuk korpus paralel bahasa Lampung-Indonesia dan 9702 kalimat untuk mono korpus bahasa Indonesia maka diperoleh, hasil pengujian kalimat bahasa Lampung dengan pendekatan SMT, nilai seperti tertera dalam tabel 3 di bawah ini.

Tabel 3. Hasil pengujian kalimat bahasa Lampung dengan SMT

\begin{tabular}{lc}
\hline \multicolumn{1}{c}{ Nilai BLUE } & Hasil Akurasi SMT (\%) \\
\hline 25 Kalimat Tunggal tanpa OOV & 77.07 \\
25 Kalimat Tunggal dengan OOV & 72.29 \\
25 Kalimat Majemuk tanpa OOV & 79.84 \\
25 Kalimat Majemuk dengan OOV & 80.84 \\
\hline
\end{tabular}




\subsection{Analisa Hasil Pengujian Kalimat Bahasa Lampung dengan SMT}

Hasil pengujian kalimat bahasa Lampung dengan SMT mendapatkan nilai seperti tertera dalam tabel 3. Faktor utama keberhasilan penerjemahan kalimat bahasa Lampung ke bahasa Indonesia adalah adanya kecocokan data trigram atau bigram atau unigram di kalimat uji dengan data trigram atau bigram atau unigram di korpus paralel. Selanjutnya diamati hasil pengujian pada kalimat tunggal tanpa out-of-vocabulary disingkat menjadi TTOOV, kalimat tunggal dengan out-of-vocabulary disingkat menjadi TDOOV, kalimat majemuk tanpa out-of-vocabulary disingkat menjadi MTOOV dan kalimat majemuk dengan out-of-vocabulary disingkat menjadi MDOOV.

\subsubsection{Analisa Hasil Penerjemahan pada TTOOV dan TDOOV}

Hasil pengujian pada kalimat tunggal tanpa out-of-vocabulary (TTOOV) sebesar $77.07 \%$ dan kalimat tunggal dengan out-of-vocabulary (TDOOV) sebesar $72.29 \%$. Angka tersebut mencerminkan kemampuan mesin dalam menerjemahkan kalimat uji sesuai acuan kalimat referensi. Walau demikian, tetap ditemukan beberapa kesalahan penerjemahan yang terjadi karena dua faktor, yaitu (1) hasil kecocokan data trigram atau bigram atau unigram di kalimat uji dengan data trigram atau bigram atau unigram di korpus paralel, (2) kata tersebut terdeteksi sebagai out-of-vocabulary. Pada kalimat tunggal yang sengaja diberikan out-of-vocabulary, keberadaan out-of-vocabulary tersebut tidak mengacaukan/mengganggu konteks kalimat. Di bawah ini diberikan contoh atas dua faktor kegagalan penerjemahan tersebut dan diberikan pada tabel .

Tabel 4. Contoh kesalahan karena faktor pertama pada TTOOV

\begin{tabular}{lll}
\hline $\begin{array}{c}\text { Kalimat dalam Bahasa } \\
\text { Lampung }\end{array}$ & \multicolumn{1}{c}{$\begin{array}{c}\text { Referensi Arti dalam } \\
\text { Bahasa Indonesia }\end{array}$} & \multicolumn{1}{c}{ Hasil SMT } \\
\hline $\begin{array}{l}\text { nyak mak mepoh kawai } \\
\text { di wai }\end{array}$ & $\begin{array}{l}\text { saya tidak mencuci baju di } \\
\text { sungai }\end{array}$ & $\begin{array}{l}\text { saya tidak mencuci kain } \\
\text { di sungai }\end{array}$ \\
\hline
\end{tabular}

Dalam bahasa Lampung, kata 'kawai' memiliki dua makna yaitu 'baju' dan 'kain'. Dalam pemakaiannya di korpus paralel lebih banyak kata 'kawai' diartikan sebagai 'baju', akan tetapi karena variasi data trigram atau bigram atau unigram di kalimat tersebut mesin SMT menemukan kecocokan kata 'kawai' diartikan sebagai 'kain' daripada 'baju'.

Tabel 5. Contoh kesalahan karena faktor kedua pada TTOOV

\begin{tabular}{lll}
\hline $\begin{array}{c}\text { Kalimat dalam Bahasa } \\
\text { Lampung }\end{array}$ & \multicolumn{1}{c}{$\begin{array}{c}\text { Referensi Arti dalam } \\
\text { Bahasa Indonesia }\end{array}$} & \multicolumn{1}{c}{ Hasil SMT } \\
\hline $\begin{array}{l}\text { hikam miwang ulah } \\
\text { cukukku tiinjik }\end{array}$ & $\begin{array}{l}\text { hamba menangis karena } \\
\text { kakiku terinjak }\end{array}$ & $\begin{array}{l}\text { hamba menangis karena } \\
\text { kakiku tiinjik }\end{array}$ \\
\hline
\end{tabular}

Pada tabel 5 diketahui bahwa kata 'tiinjik' terdeteksi tidak ada dalam koprus paralel sehingga mesin SMT mendeteksinya sebagai unknown word.

Tabel 6. Contoh kesalahan karena faktor pertama pada TDOOV

\begin{tabular}{lll}
\hline $\begin{array}{c}\text { Kalimat dalam Bahasa } \\
\text { Lampung }\end{array}$ & \multicolumn{1}{c}{$\begin{array}{c}\text { Referensi Arti dalam } \\
\text { Bahasa Indonesia }\end{array}$} & \multicolumn{1}{c}{ Hasil SMT } \\
\hline $\begin{array}{l}\text { nyak mak mepoh kawai } \\
\text { di wai brantas }\end{array}$ & $\begin{array}{l}\text { saya tidak mencuci baju di } \\
\text { sungai brantas }\end{array}$ & $\begin{array}{l}\text { saya tidak mencuci kain } \\
\text { di sungai brantas }\end{array}$ \\
\hline
\end{tabular}

Seperti halnya tertera pada tabel 4, dalam hal yang perlu diamati adalah di kalimat tesebut terdapat kata 'brantas' yang tidak ada dalam korpus paralel sehingga mesin SMT mendeteksi sebagai unknown word dan tidak menggangu konteks kalimat.

Tabel 7. Contoh kesalahan karena faktor kedua pada TDOOV

\begin{tabular}{lll}
\hline $\begin{array}{c}\text { Kalimat dalam Bahasa } \\
\text { Lampung }\end{array}$ & \multicolumn{1}{c}{$\begin{array}{c}\text { Referensi Arti dalam } \\
\text { Bahasa Indonesia }\end{array}$} & \multicolumn{1}{c}{ Hasil SMT } \\
\hline $\begin{array}{l}\text { ani sina helaw gegoh } \\
\text { bidadaghi }\end{array}$ & $\begin{array}{l}\text { ani itu cantik seperti } \\
\text { bidadari }\end{array}$ & $\begin{array}{l}\text { ani itu cantik seperti } \\
\text { bidadaghi }\end{array}$ \\
\hline
\end{tabular}

Kata 'bidadaghi' terdeteksi tidak ada dalam koprus paralel sehingga mesin SMT mendeteksinya sebagai unknown word. Penurunan nilai BLEU pada kalimat tunggal dengan out-of-vocabulary dibandingan dengan kalimat tunggal tanpa out-of-vocabulary adalah karena terjadi variasi pencocokan data variasi data trigram atau bigram atau unigram yang lebih tinggi pada kalimat tunggal dengan out-of-vocabulary dibandingan dengan kalimat tunggal tanpa out-of-vocabulary. 


\subsubsection{Analisa Hasil Penerjemahan pada MTOOV dan MDOOV}

Hasil pengujian pada kalimat majemuk tanpa out-of-vocabulary $79.84 \%$ dan pada kalimat majemuk dengan outof-vocabulary $80.84 \%$, angka tersebut mencerminkan kemampuan mesin dalam menerjemahkan kalimat uji sesuai acuan kalimat referensi. Detail hasil penerjemahan kalimat bahasa Lampung ke bahasa Indonesia terdapat di lampiran J. Kalimat majemuk, kalimat yang lebih panjang dari kalimat tunggal. Hal ini memberikan keuntungan tingkat variasi yang lebih tinggi pada kalimat majemauk dibandingkan kalimat tunggal dalam hal kecocokan data trigram atau bigram atau unigram di kalimat uji dengan data trigram atau bigram atau unigram di korpus paralel. Penambahan out-of-vocabulary pada kalimat majemuk tidak mengganggu konteks kalimat bahkan berkontribusi $1 \%$ pada kenaikan nilai BLEU. Walau demikian, tetap ditemukan beberapa kesalahan penerjemahan yang terjadi karena tiga faktor, yaitu (1) hasil penerjemahan kata yang serupa, (2) hasil kecocokan data trigram atau bigram atau unigram di kalimat uji dengan data trigram atau bigram atau unigram di korpus paralel, (3) kata tersebut terdeteksi sebagai out-of-vocabulary. Pada kalimat majemuk yang sengaja diberikan out-of-vocabulary, keberadaan out-of-vocabulary tersebut tidak mengacaukan / mengganggu konteks kalimat. Di bawah ini diberikan contoh atas tiga faktor kegagalan penerjemahan tersebut.

Tabel 8. Contoh kesalahan karena faktor pertama pada MTOOV

\begin{tabular}{lcl}
\hline $\begin{array}{c}\text { Kalimat dalam Bahasa } \\
\text { Lampung }\end{array}$ & $\begin{array}{c}\text { Referensi Arti dalam } \\
\text { Bahasa Indonesia }\end{array}$ & \multicolumn{1}{c}{ Hasil SMT } \\
\hline $\begin{array}{l}\text { apakni lapah mit sabah } \\
\text { ghik ibuni lapah mit } \\
\text { pasagh }\end{array}$ & $\begin{array}{l}\text { bapaknya pergi ke sawah } \\
\text { dan ibunya pergi ke pasar }\end{array}$ & $\begin{array}{l}\text { ayahnya pergi ke sawah } \\
\text { dan ibunya pergi ke pasar }\end{array}$ \\
\hline
\end{tabular}

Dalam bahasa Lampung, kata 'apakni' memiliki dua makna yaitu 'bapaknya' dan 'ayahnya'. Dalam pemakaiannya di korpus paralel lebih banyak kata 'apaknya' diartikan sebagai 'bapaknya', akan tetapi karena variasi data trigram atau bigram atau unigram di kalimat tersebut mesin SMT menemukan kecocokan kata 'apakni' diartikan sebagai 'ayahnya' daripada 'bapaknya'.

Tabel 9. Contoh kesalahan karena faktor kedua pada MTOOV

\begin{tabular}{lll}
\hline $\begin{array}{c}\text { Kalimat dalam Bahasa } \\
\text { Lampung }\end{array}$ & \multicolumn{1}{c}{$\begin{array}{c}\text { Referensi Arti dalam } \\
\text { Bahasa Indonesia }\end{array}$} & \multicolumn{1}{c}{ Hasil SMT } \\
\hline tamong ni lapah mit & kakeknya pergi ke ladang & kakek dan nenek nya \\
huma ghik nyaik $n i$ & dan nenek nya menyapu di \\
nyapu di lambanni & rumahnya & $\begin{array}{l}\text { pergi ke kebun nya } \\
\text { menyapu di rumahnya }\end{array}$ \\
\hline
\end{tabular}

Pada tabe 9 terjadi penerjemahan yang tidak beraturan hasil pencocokan kalimat uji tersebut terhadap temuan variasi data trigram atau bigram atau unigram di mesin SMT. Pada tabel 10 di bawah ini, kesalahan karena faktor kedua bahkan berakibat hilangnya sebuah kata pada kalimat uji yaitu kata'karang'.

Tabel 10. Contoh kesalahan karena faktor kedua pada MTOOV

\begin{tabular}{lll}
\hline $\begin{array}{c}\text { Kalimat dalam Bahasa } \\
\text { Lampung }\end{array}$ & \multicolumn{1}{c}{$\begin{array}{c}\text { Referensi Arti dalam } \\
\text { Bahasa Indonesia }\end{array}$} & \multicolumn{1}{c}{ Hasil SMT } \\
\hline ani ghik ana lapah mit & ani dan ana pergi ke & ani dan ana pergi ke \\
tanjung karang kanah & tanjung karang nanti sore & $\begin{array}{l}\text { karang tanjung nanti sore } \\
\text { kebi amun ibuni pedom }\end{array}$ \\
kalau ibunya tidur & kalau ibunya tidur \\
\hline
\end{tabular}

Pada tabel 11 di bawah ini terjadi dua kesalahan secara beururutan yang dihasilkan dari mesin SMT, yaitu pada penerjemahan kata 'mak' dan kata 'tiinjik'. Kata 'mak' seharusnya diterjemahkan sebagai 'tidak' bukan 'ibu', sedangkan kata 'tiinjik' terdeteksi sebagai out-of-vocabulary.

Tabel 11. Contoh kesalahan karena faktor kedua dan ketiga pada MTOOV

\begin{tabular}{lllll}
\hline $\begin{array}{c}\text { Kalimat dalam Bahasa } \\
\text { Lampung }\end{array}$ & \multicolumn{2}{c}{$\begin{array}{c}\text { Referensi Arti dalam } \\
\text { Bahasa Indonesia }\end{array}$} & \multicolumn{2}{c}{ Hasil SMT } \\
\hline $\begin{array}{l}\text { nyak mak sakik walau } \\
\text { cukukku tiinjik }\end{array}$ & $\begin{array}{l}\text { saya tidak sakit walau } \\
\text { kakiku terinjak }\end{array}$ & $\begin{array}{l}\text { saya ibu sakit } \\
\text { kakiku tiinjik }\end{array}$ & walau \\
\hline
\end{tabular}

Secara umum yang terjadi pada penerjemahan kalimat majemuk dengan out-of-vocabulary memberikan hasil yang sama dengan penerjemahan kalimat majemuk tanpa out-of-vocabulary. Di bawah ini diberikan contoh hasil penerjemahan penerjemahan kalimat majemuk dengan out-of-vocabulary.

Tabel 12. Contoh kesalahan karena faktor pertama dan kedua pada MDOOV 
Available Online at https://ejurnal.stmik-budidarma.ac.id/index.php/mib DOI $10.30865 /$ mib.v4i3.2116

\begin{tabular}{|c|c|c|}
\hline $\begin{array}{l}\text { Kalimat dalam Bahasa } \\
\text { Lampung }\end{array}$ & $\begin{array}{c}\text { Referensi Arti dalam } \\
\text { Bahasa Indonesia }\end{array}$ & Hasil SMT \\
\hline $\begin{array}{l}\text { bakas jama nyaik } \\
\text { mejong-mejong gawoh } \\
\text { di lamban kemiling } \\
\text { ghik apakni ghajin di } \\
\text { kantogh kobum }\end{array}$ & $\begin{array}{l}\text { kakek sama nenek duduk- } \\
\text { duduk saja di rumah } \\
\text { kemiling dan bapaknya } \\
\text { rajin di kantor kobum }\end{array}$ & $\begin{array}{l}\text { kakek dengan nenek } \\
\text { duduk-duduk saja di } \\
\text { rumah kemiling dan } \\
\text { ayahnya rajin kobum di } \\
\text { kantor }\end{array}$ \\
\hline
\end{tabular}

Kesalahan pertama terjadi pada kata 'apakni', seperti dijelaskan pada tabel 8 di atas. Kesalahan kedua yaitu terjadi salah urutan penempatan hasil penerjemah pada kalimat 'ayahnya rajin kobum di kantor', seharusnya kalimat yang dihasilkan adalah 'ayahnya rajin di kantor kobum'.

Mesin penerjemah dengan pendekatan SMT mampu menerjemahkan kalimat dengan hasil keluaran urutan kosa kata sesuai kalimat dalam bahasa Indonesia dengan tingkat kemapuan sesuai tertera pada tabel IV.4. Kelemahan mesin SMT adalah (1) mesin tidak dapat memahami konteks kalimat, (2) mesin hanya bekerja berdasarkan kecocokan variasi kecocokan data trigram atau bigram atau unigram di kalimat uji dengan data trigram atau bigram atau unigram di korpus paralel.

\section{KESIMPULAN}

Berdasarkan hasil pemaparan pada hasil dan pembahasan maka diperoleh kesimpulan dari penelitian ini sebagai berikut :

1. Penerjemahan kalimat bahasa Lampung ke bahasa Indonesia dapat dilakukan dengan pendekatan SMT.

2. Bahan penelitian diperoleh dengan melakukan wawancara dengan penutur bahasa Lampung dialek api dan melalui pencarian ke berbagai buku ajar bahasa Lampung tingkat SD dan SMP.

3. Pada eksperimen dengan pendekatan SMT dilakukan dengan beberapa fase. Dimulai dari fase prapemrosesan yang merupakan tahapan awal untuk mempersiapkan korpus parallel. Kemudian dilanjutkan dengan fase training, yakni fase pengolahan korpus parallel untuk memperoleh language model dan translation model. Selanjutnya fase testing, dan diakhiri dengan fase evaluasi. Pengujian SMT menggunakan 25 kalimat tunggal tanpa out-of-vocabulary (OOV), 25 kalimat tunggal dengan OOV, 25 kalimat majemuk tanpa OOV dan 25 kalimat majemuk dengan OOV.

4. Hasil pengujian penerjemahan kalimat bahasa Lampung ke bahasa Indonesia menunjukan nilai akurasi Bilingual Evaluation Undestudy (BLEU) yang diperoleh adalah $77.07 \%$ pada 25 kalimat tunggal tanpa outof-vocabulary (OOV), $72.29 \%$ pada 25 kalimat tunggal dengan OOV, $79.84 \%$ pada 25 kalimat majemuk tanpa OOV dan $80.84 \%$ pada 25 kalimat majemuk dengan OOV. Pendekatan dengan SMT mampu membangkitkan variasi data unigram, bigram atau trigram dari 3000 kalimat pada korpus paralel dan 9702 kalimat pada mono korpus bahasa Indonesia sehingga memperbesar peluang terjadinya pencocokan antara variasi data unigram, bigram atau trigram kalimat uji dengan kalimat yang ada di dalam data training SMT.

\section{UCAPAN TERIMAKASIH}

Penulis mengucapkan terima kasih kepada Kementrian Riset dan Teknologi / Badan Riset dan Inovasi Nasional yang telah memberi dukungan financial terhadap penelitian ini melalui skema Penelitian Dosen Pemula (PDP) tahun 2020.

\section{REFERENCES}

[1] L. Post, "Nestapa Guru Bahasa Lampung,” Lampung Post, Bandar Lampung, Jul. 2017.

[2] Antara, "139 Bahasa Daerah di Indonesia Terancam Punah,” Republika.co.id, Bandung, Aug. 2016.

[3] P. Bhattacharyya, Machine Translation. Boca Raton: Taylor \& Francis Group, 2015.

[4] A. Maslan, Y. Setiono, and F. Alfazri, "Pengembangan Smart Application Translation Aneka Bahasa Sulawesi Berbasis Android," TEKNOSI, vol. 02, no. 01, pp. 55-64, 2016.

[5] R. Nugroho Aditya, T. Adji Bharata, and B. Hantono S, "Penerjemahan Bahasa Indonesia dan Bahasa Jawa Menggunakan Metode Statistik Berbasis Frasa," Semin. Nas. Teknol. Inf. dan Komun., vol. 2015, no. Sentika, 2015.

[6] F. Rohman, P. W. Buana, A. Agung, and K. Wiranata, "Rancang Bangun Penerjemah Bahasa Indonesia ke Bahasa Jawa Berbasis Android," J. Ilm. Merpati (Menara Penelit. Akad. Teknol. Informasi), vol. 3, no. 1, pp. 40-47, 2015.

[7] N. Afifah, T. B. Santoso, and M. Yuliana, "Pembuatan Kamus Elektronik Kalimat Bahasa Indonesia dan Bahasa Jawa untuk Aplikasi Mobile Menggunakan Interpolation Search,” Semin. Proy. Akhir Jur. Tek. Telekomun. PENS-ITS, pp. 17, 2010.

[8] K. T. C. Resmawan, I. K. R. Arthana, and I. M. G. Sunarya, "Pengembangan Aplikasi Kamus Dan Penerjemah Bahasa Indonesia-Bahasa Bali Menggunakan Metode Rule Based Berbasis Android," KARMAPATI (Kumpulan Artik. Mhs. Pendidik. Tek. Inform., vol. 4, no. 2, pp. 70-81, 2015.

[9] R. M. M. Shalini and B. Hettige, "Dictionary Based Machine Translation System for Pali to Sinhala," Sri Lanka, no. October 2017, p. 6, 2017.

[10] D. V Sindhu and B. M. Sagar, "Dictionary Based Machine Translation from Kannada to Telugu," IOP Conf. Ser. Mater. 
JURNAL MEDIA INFORMATIKA BUDIDARMA

Volume 4, Nomor 3, Juli 2020, Page 519-528

ISSN 2614-5278 (media cetak), ISSN 2548-8368 (media online)

Available Online at https://ejurnal.stmik-budidarma.ac.id/index.php/mib

DOI $10.30865 /$ mib.v4i3.2116

Sci. Eng., vol. 225, p. 012182, 2017, doi: 10.1088/1757-899x/225/1/012182.

[11] A. A. Suryani, D. H. Widyantoro, A. Purwarianti, and Y. Sudaryat, "Experiment on a phrase-based statistical machine translation using PoS Tag information for Sundanese into Indonesian," 2015 Int. Conf. Inf. Technol. Syst. Innov. ICITSI 2015 - Proc., 2016, doi: 10.1109/ICITSI.2015.7437678.

[12] T. Apriani, H. Sujaini, and N. Safriadi, "Pengaruh Kuantitas Korpus Terhadap Akurasi Mesin Penerjemah Statistik Bahasa Bugis Wajo Ke Bahasa Indonesia," J. Sist. dan Teknol. Inf., vol. 1, no. 1, pp. 1-6, 2016.

[13] C. Adiputra, Krisna and Y. Arase, "Performance of Japanese-to-Indonesian Machine Translation on Different Models," Proc. 23rd Annu. Meet. Linguist. Process. Soc., no. C, pp. 7-10, 2017.

[14] H. Sujaini, "Meningkatkan Peran Model Bahasa dalam Mesin Penerjemah Statistik (Studi Kasus Bahasa IndonesiaDayak Kanayatn)," Khazanah Inform. J. Ilmu Komput. dan Inform., vol. 3, no. 2, p. 51, 2017, doi: 10.23917/khif.v3i2.4398.

[15] H. Tanuwijaya and H. Manurung, Maruli, "Penerjemah Dokumen Inggris-Indonesia Menggunakan Mesin Penerjemah Statistik Dengan Word Reordering dan Phrase Reordering," J. Ilmu Komput. dan Inf., vol. 2, no. 1, pp. 17-24, 2009.

[16] Z. Abidin, A. Sucipto, and A. Budiman, "Penerjemahan Kalimat Bahasa Lampung-Indonesia Dengan Pendekatan Neural Machine Translation Berbasis Attention Translation of Sentence Lampung-Indonesian Languages With Neural Machine Translation Attention Based," J. Kelitbangan, vol. 06, no. 02, pp. 191-206, 2018.

[17] Z. Abidin, "Penerapan Neural Machine Translation untuk Eksperimen Penerjemahan secara Otomatis pada Bahasa Lampung - Indonesia," Pros. Semin. Nas. Metod. Kuantitatif 2017, no. 978, pp. 53-68, 2017.

[18] K. Papineni, S. Roukos, T. Ward, and W.-J. Zhu, "BLEU: a Method for Automatic Evaluation of Machine Translation," Proc. 40th Annu. Meet. Assoc. Comput. Linguist., pp. 311-318, 2002, doi: 10.1002/andp.19223712302.

[19] Megaria, "Afiks Pembentuk Adjektiva dalam Bahasa Lampung Dialek A Logat Belalau (Analisis Morfologis)," $J$. LOKABASA, vol. 4, no. 2, pp. 195-201, 2013. 